\title{
PERAN GEMBALA JEMAAT TERHADAP PENGEMBANGAN PELAYANAN HOLISTIK DI GEREJA KEMAH INJIL INDONESIA JEMAAT YEGAR SAHADUTA JAYAPURA
}

\author{
Reinhard Jeffray Berhitu \\ Sekolah Tinggi Teologi Levinus Rumaseb Jayapura \\ rein.berhitu@yahoo.com
}

\begin{abstract}
Abstrak
Tujuan yang hendak dicapai dalam tulisan ini antara lain: Pertama, membahas peranan gembala jemaat terhadap pengembangan pelayanan holistik. Kedua, menemukan bentuk-bentuk pelayanan holistik yang efektif untuk memenuhi kebutuhan jemaat GKII Jemaat Yegar Sahaduta Jayapura. Ketiga, membahas hambatan dan penerapan pelayanan holistik di Gereja Kemah Injil Indonesia (GKII) Jemaat Yegar Sahaduta Jayapura. Peranan Gembala Jemaat dalam pelayanan holistik adalah menentukan visi dan misi gereja, mendelegasikan tugas, memberi pertimbangan, pelayanan mimbar, menjaga kebutuhan dan persekutuan jemaat dengan Allah.

Kata-kata kunci: Peran gembala, pelayanan holistik, mimbar, persekutuan

The goals, among others, which are hoped to be achieved in this article are: First, to discuss the role of the congregational pastor in the development of a holistic ministry. Second, to discover the forms of holistic ministry which are effective for meeting the needs of the Yegar Sahaduta Church of the Gereja Kemah Injil Indonesia in Jayapura. Third, to discuss the obstacles and application of holistic ministries in the Yegar Sahaduta Church of the Gereja Kemah Inji Indonesia in Jayapura. The roleof the congregational pastor in holistic ministries includes establishing the vision and mission of the church, delegating responsibilities, giving opinions, ministering in the pulpit, and caring for the needs and fellowship of the church with God.
\end{abstract}

Keywords: pastoral role, holistic ministry, pulpit, fellowship

\section{Pendahuluan}

Seorang gembala jemaat tidak lain adalah seorang hamba. Ia adalah seorang hamba dalam hubungannya dengan Allah (Matius 24:45). Dalam posisinya sebagai seorang gembala jemaat, ia berkewajiban untuk melayani jemaat dan bertanggung jawab terhadap Allah atas kehidupan jemaat yang digembalakannya. 
Dalam beberapa dekade yang telah lampau, pelayanan seorang gembala jemaat lebih diarahkan dan terfokus kepada pelayanan mimbar dan pelayanan pastoral lainnya, dengan tujuan untuk mengarahkan dan membangun hubungan jemaat dengan Allah. Pelayanan tersebut adalah pelayanan yang sangat penting karena hal memberitakan Injil dan membawa jiwa-jiwa kepada Tuhan adalah perintah dan Amanat Agung dari Tuhan Yesus sendiri sebelum Ia terangkat naik ke surga (Matius 28:19-20). Perintah tersebut adalah perintah khusus dan utama yang harus dikerjakan oleh seorang gembala jemaat atau pelayan umat, yang menyentuh kehidupan rohani dari tiap-tiap jemaat yang dilayaninya.

Ralph M. Riggs mengatakan, bahwa pelayanan seorang pendeta (gembala jemaat) meliputi tugas-tugas dan tujuan tertentu. Yang paling utama adalah memberitakan firman. Allah telah menetapkan bahwa dengan kebodohan pemberitaan Injil manusia akan diselamatkan (1 Korintus 1:21). ${ }^{1}$

Pelayanan pemberitaan firman memang merupakan sebuah pelayanan yang sangat penting karena menyangkut keselamatan manusia. Tetapi, pada masa sekarang ini seorang gembala jemaat juga dituntut untuk tidak saja memerhatikan kehidupan rohani dari jemaat yang dilayaninya, tetapi juga harus memerhatikan kehidupan jasmani jemaat tersebut. Ini adalah sebuah bentuk pelayanan yang tidak kalah pentingnya dengan pelayanan pemberitaan firman.

\section{Pengertian Pelayanan Holistik}

Bentuk pelayanan holistik semata-mata bukanlah milik dari gereja atau lembaga pelayanan Kristen, tetapi juga dilakukan oleh lembaga-lembaga lain di luar kekristenan. Tetapi, dari pelayanan yang dilakukannya, ada hal yang sangat penting yang membuat pelayanan holistik gerejawi berbeda dengan pelayanan lainnya, yakni menyenangkan hati Tuhan.

Hal prinsipil yang membuat pelayanan holistik gerejawi berbeda dari pelayanan holistik lainnya, yaitu: ${ }^{2}$

Pertama, motivasi dari pelayanan itu sendiri. Motivasi pelayanan kristiani adalah pelayanan Kristus sendiri. Artinya sebelum pelayanan ini dilakukan karena keinginan untuk melayani Kristus, atau lebih tepat lagi, melayani Kristus melalui pelayanan kepada sesama, oleh karena Kristus telah lebih dahulu melayani umat-Nya.

\footnotetext{
${ }^{1}$ Ralph M. Riggs, Gembala Sidang Yang Berhasil (Malang: Yayasan Penerbit Gandum Mas, 1996), 71.

${ }^{2}$ Sabda "Pengertian Pelayanan Holistik", diakses 27 Oktober 2013, http://alkitab.sabda. org/resource.php?topic=493\&res=jpz
} 
Kedua, yang harus menjadi pendorong melakukan suatu pelayanan adalah karena ketaatan kepada Kristus. Allah menghendaki supaya orang percaya saling melayani satu sama lain. Tuhan Yesus di dalam Yohanes 13:14-15 mengatakan, "Jadi jikalau Aku membasuh kakimu, Aku yang adalah Tuhan dan Gurumu, maka kamu pun wajib saling membasuh kakimu; sebab Aku telah memberikan suatu teladan kepada kamu, supaya kamu juga berbuat sama seperti yang telah Kuperbuat kepadamu." Pelayanan adalah sebuah kewajiban yang harus dilakukan oleh setiap orang Kristen. Dengan demikian, tidak melakukan pelayanan adalah contoh ketidaktaatan kepada Kristus. Melayani bukan supaya memperoleh sesuatu, tetapi sebaliknya, karena telah memperoleh sesuatu dari Allah.

Ketiga, yang membuat pelayanan kristiani itu berbeda adalah karena pelayanan kristiani berpola pada pelayanan Kristus sendiri (Yohanes 12:26; 13:14). Adapun pola pelayanan Yesus adalah: (a) Pelayanan Kristus ditentukan oleh ketaatan yang sepenuhnya kepada Allah dan kasih kepada sesama manusia. Orientasi pelayanan Kristiani adalah kehendak Allah dan kebutuhan mereka yang dilayani. Bukan kepentingan kita pribadi; (b) Pelayanan Kristus diwujudkan dalam bentuk identifikasi dan solidaritas (Yohanes 1:12; Filipi 2:7). Tidak berdiri lebih tinggi (filantropis), tetapi juga tidak duduk lebih rendah daripada yang dilayani, melainkan menempatkan diri sepenuhnya pada tempat mereka yang dilayani. Ikut merasakan apa yang dirasakan oleh mereka yang dilayani. Oleh karena itu pelayanan kristiani harus disertai dengan respek, simpati, dan empati yang dalam; (c) Pelayanan Kristus adalah pelayanan yang holistik, artinya pelayanan yang utuh dan menyeluruh. Oleh karena itu, pelayanan Kristiani adalah mewujudnyatakan Injil yang utuh bagi manusia yang utuh. Holistik artinya melihat kebutuhan manusia baik kebutuhankebutuhan individualnya maupun sosialnya baik kebutuhankebutuhan fisik, psikis maupun kebutuhan spiritualnya, baik kebutuhan-kebutuhan sekarang di bumi ini maupun nanti setelah mati, dan sebagainya.

\section{Peran Gembala Jemaat dalam Pelayanan Holistik}

Gembala Gereja Kemah Injil Indonesia Jemaat Yegar Sahaduta Jayapura Papua memiliki beberapa peranan utama dalam menggembangkan pelayanan holistik.

\section{Menentukan Visi dan Misi Gereja}

Gembala sebagai pribadi yang bertanggungjawab kepada Kristus sebagai Gembala Agung yang memanggil, memilih sebagai pelayan Tuhan mempunyai peran yang sangat vital, yaitu menentukan visi 
gereja di mana Tuhan menempatkannya. Sebuah Gereja tidak akan mengalami pertumbuhan dan perkembangan yang signifikan bilamana gembala tidak mempunyai visi dan misi yang jelas. Penetapan visi dan misi hendaklah dimulai dari gembala dan ini merupakan tugas awal dalam memulai sebuah pelayanan baru dalam jemaat Kristus.

\section{Mendelegasikan Tugas}

Selain menentukan visi dan misi gereja, peran utama gembala jemaat adalah mendelegasikan tugas-tugas pelayanan. Dalam organisasi Gereja Kemah Injil Indonesia (GKII) Yegar Sahaduta secara struktural gembala adalah sebagai ketua majelis jemaat dan sebagai Badan Pekerja Jemaat (BPJ), pelayan pembantu, serta para majelis jemaat. Patriot Kayoi mengatakan, "Pelayanan dalam bidang musik gereja dan penghubung pemuda telah didelegasikan oleh gembala kepada saya." " Emmy Mariani mengatakan, "Gembala telah mendelegasikan tugas pelayanan kepada saya untuk mengkoordinir pelayanan di bidang liturgi dan penetapan jadwal ibadah minggu pagi dan secara khusus dalam pembinaan warga jemaat." ${ }^{4}$ Hal yang sama dikatakan oleh Antomina Nuboba, "Gembala telah mendelegasikan tugas pelayanan untuk melaksanakan pelayanan pengelolaan rumah tangga gereja." ${ }^{5}$ Eko Watimena mengatakan, "Gembala telah mendelegasikan untuk mengelola, mengatur, dan memelihara sound system gereja." Hal serupa dikatakan oleh ibu Katrin Nussi, "Gembala telah mendelegasikan tugas pelayanan diakonia dan tugas sebagai pelayan koordinator diakonia jemaat." ${ }^{7}$

\section{Memberi Pertimbangan atas Program Strategis}

Peran seorang gembala jemaat ialah "Memberikan pertimbangan atas program strategis." Silvana Lewerisa bendahara Gereja Kemah Injil Indonesia (GKII) jemaat Yegar Sahaduta mengatakan bahwa "Seorang gembala dalam kapasitasnya sebagai ketua Badan Pengurus Jemaat (BPJ) bersama anggota Badan Pengurus Jemaat (BPJ) memberikan pertimbangan atas program dalam gereja baik yang menyangkut fisik maupun non fisik. Dalam perekrutan (proses) pekerja Gereja Kemah Injil Indonesia (GKII), khususnya Jemaat Yegar Sahaduta dapat dipertanggungjawabkan kepada jemaat." ${ }^{8}$ Hal senada

\footnotetext{
${ }^{3}$ Patriot Kayoi, Wawancara Oleh Penulis, 19 Juni 2013.

${ }^{4}$ Emmy Mariani, Wawancara Oleh Penulis, 08 Juni 2013.

${ }^{5}$ Antomina Mangku, Wawancara Oleh Penulis, ll Juni 2013.

${ }^{6}$ Eko Watimena, Wawancara Oleh Penulis, 10 Juni 2013.

${ }^{7}$ Katrin Nussi, Wawancara Oleh Penulis, ll Juni 2013.

${ }^{8}$ Silvana Lawerissa, Wawancara Oleh Penulis, Jayapura, 12 Mei 2013.
} 
juga disampaikan oleh Exi Karubui sebagai wakil ketua pelayanan anak dan remaja Yegar Sahaduta mengatakan bahwa "Pelayanan anak memang indepeden, namun semua program dan termasuk usulan penambahan guru sekolah minggu, kurikulum dan kegiatan-kegiatan keluar yang perlu mendapat pertimbangan gembala. ${ }^{9}$

Pengembangan gereja yang sesuai dengan norma-norma pertumbuhan gereja tentu memperhatikan arahan-arahan dari gembala, dan juga diberikan kesempatan kepada semua unsur organisasi untuk membuat program dan usulan-usulan, namun semuanya harus mendapat pertimbangan dan persetujuan dari gembala dan Badan Pekerja Jemaat (BPJ). Theo Ruamba, wakil ketua majelis jemaat Yegar Sahaduta mengatakan bahwa, "Bilamana ada unsur atau seksi yang mengajukan usulan program dan memerlukan biaya, Badan Pekerja Jemaat (BPJ) akan mengadakan pertemuan yang dipimpin oleh Gembala selaku Ketua Majelis Jemaat dan usulan tersebut dipertimbangkan oleh $\mathrm{BPJ}$, dalam hal ini bersama dengan gembala." 10

\section{Pelayanan Mimbar}

Dari pengamatan penulis sebagai gembala, pelayanan mimbar merupakan salah satu peran yang sangat menonjol dari gembala dalam hal ini adalah berkhotbah. Hampir dalam setiap minggu gembala tampil untuk berkhotbah, baik dalam ibadah minggu pagi, ibadah keluarga dan ibadah unsur atau seksi bahkan dalam kegiatankegiatan khusus gerejawi. Untuk pelayanan ekstrenal, gembala juga mengikuti jadwal pertukaran mimbar dalam lingkup Gereja Kemah Injil Indonesia (GKII) Daerah Pantai. Ini berarti gembala tidak hanya berkhotbah pada jemaat Yegar Sahaduta, tetapi juga bermitra dengan gereja lain.

\section{Menjaga Keutuhan dan Persekutuan Jemaat dengan Allah}

Peranan yang satu ini merupakan peranan yang sangat berat karena punya hubungan dengan Yesus sebagai kepala gereja yang mempercayakan peran ini kepada gembala. Gembala yang tidak menjaga hubungan relasi yang intim dengan Allah dapat merusak kawanan gembalaannya. Oleh sebab itu, peran yang paling penting bagi seorang gembala adalah bagaimana kehidupannya menjadi contoh bagi anggota jemaat atau umat yang dipimpinnya.

Identitas dan mentalitas seorang gembala yang baik sangat ditentukan seberapa jauh hubungan pribadinya dengan Kristus sebagai kepala gereja itu. Karena gembala adalah model, contoh dan

\footnotetext{
${ }^{9}$ Exie Karubui Kayoi, Wawancara Oleh Penulis, Jayapura, 19 Mei 2013.

${ }^{10}$ Teo Ruamba, Wawancara Oleh Penulis, Jayapura, 07 April 2013.
} 
bapak rohani bagi domba maka segala gerak-geriknya menjadi cermin bagi anggota jemaat, dan tuntutan yang tatkala penting adalah menjaga persekutuan yang baik dengan Kristus.

Petrus Daisiu, Ketua Daerah Pantai mengatakan bahwa, "Peran dan tanggung jawab sebagai gembala yang paling utama adalah menjaga, memproteksi semua kegiatan yang bertujuan menjaga persekutuan dengan Allah Tritunggal dan hidup dipimpin, diurapi oleh Roh Kudus." ${ }^{\prime \prime}$ Sebagai gembala senior tentu, hal ini menjadi prioritas utama yang harus dilakukan. Dengan melakukan hal yang demikian secara nyata dan jelas kehidupan rohani jemaat dapat terbina dengan baik, karena gembala menjaga persekutuan yang baik dengan Allah dan hidup dalam pengurapan Roh Kudus.

\section{Pelayanan Diakonia GKII Jemaat Yegar Sahaduta Jayapura}

George Barna mengatakan, "Tuhan Yesus harus menjadi model dalam pelayanan dan pemasaran. Sama seperti Tuhan Yesus, kita juga harus menjadi sedemikian berdedikasi, dan tenggelam di dalam pengembangan kekristenan sehingga kekristenan itu menjadi bagian yang menyatu dengan tingkah laku kita sehari-hari. ${ }^{12}$

Gereja telah mendapat pelayanan yang besar dari Sang Pelayan Agung, yaitu Tuhan Yesus Kristus. Pelayanan yang didasarkan atas kasih yang tiada tara, Dia telah mengorbankan nyawa-Nya demi orang-orang yang dilayani (Yohanes 13:1-11; Filipi 2:7-8). Oleh sebab itu, gereja dipanggil untuk melayani sesamanya secara utuh atau holistik, supaya karya penyelamatan Allah dapat disampaikan kepada dunia sehingga terciptalah damai sejahtera. Pelayanan dilakukan dengan tulus, rendah hati, tabah, dan setia tanpa paksaan. Lima dokumen keesaan gereja mengatakan bahwa pelayanan bertujuan untuk memerhatikan, memerdekakan dan melepaskan setiap orang yang tidak dapat memenuhi kebutuhan dasar hidup mereka pada masa kini dan masa yang akan datang, mereka itu adalah orang miskin, sakit, terasing, lemah, dan terlantar, bodoh, korban bencana dan perang, terbelakang, korban ketidakadilan dan kesewenangwenangan, pelayanan diakonia juga tertuju kepada lingkungan sekitarnya, sesuai mandat Allah (Kejadian 1:28). ${ }^{13}$

Dalam pengamatan penulis dan hasil wawancara dari sejumlah responden ditemukan jawaban-jawaban yang sangat nyata tentang kehidupan jemaat. Umumnya responden mengatakan bahwa bentuk pelayanan diakonia dimengerti dan dipahami sebagai suatu pelayanan

\footnotetext{
${ }^{1 l}$ Petrus Daisiu, Wawancara Oleh Penulis, Jayapura, 02 Juni 2013.

${ }^{12}$ George Barma, Memasarkan Gereja (Bandung: Kalam Hidup, 1988), 131.

${ }^{13}$ Al Parjiyanto, et. al., Jamrut: SMP Agama Kristen Kelas IX (Solo: CV. Yoga Wahyu Pratama, n.d.), 72.
} 
yang memberikan pertolongan dan bantuan yang ditunjukan kepada warga gereja atau masyarakat di sekitar gereja yang memang memerlukan bantuan itu. Seperti mengalami himpitan ekonomi, oleh karena bencana alam, perang suku, keluarga yang mengalami dukacita atau kematian, yatim piatu, janda, duda, maka dalam hal ini ada beberapa anggota yang memberikan tanggapan. Katrin Nussi majelis bidang pelayanan diakonia mengatakan, "Pelayanan diakonia dalam gereja sangat penting untuk menolong serta memberikan bantuan kepada para janda-janda, anak yatim piatu untuk meningkatkan kualitas hidup jemaat secara utuh baik secara jasmani dan rohani sebagai upaya bagi pengembangan dan pertumbuhan gereja secara kualitas iman."14

Berdasarkan hasil data wawancara dari sejumlah responden dan penulis sebagai gembala langsung, maka dapat dikatakan bahwa pemahaman anggota Gereja Kemah Injil Indonesia (GKII) terhadap bentuk pelayanan yang bersifat holistik adalah pelayanan diakonia, yaitu pelayanan secara khusus yang ditujukan kepada mereka yang memerlukan bantuan secara materi maupun secara moril bagi jandajanda, duda, anak yatim piatu, orang sakit, orang meninggal, semua ini merupakan bagian dari panggilan gereja dalam menjalankan konsep penggembalaan guna menyentuh sendi-sendi kehidupan dari warga jemaat secara jasmani dan rohani. Vence Yesianda mengatakan, "Pelayanan diakonia adalah salah satu pelayanan yang sangat memerlukan perhatian khusus dari jemaat karena menyangkut kebutuhan dan keperluan tatkala masih berada di dalam dunia." ${ }^{15}$

Berdasarkan hasil data wawancara dari sejumlah respoden dan melalui pengamatan penulis yang telah dijabarkan di atas, maka penulis menarik suatu kesimpulan bahwa pelayanan diakonia merupakan implementasi dari panggilan Tuhan kepada gereja dalam menjalankan amanah Tuhan Yesus Kristus untuk menjawab kebutuhan jasmani dan rohani secara utuh.

\section{Pelayanan Sosial}

Selain menetapkan pelayanan diakonia sebagai bagian yang sangat integral dalam panggilan pelayanan, maka pelayanan yang diharapkan untuk membawa pertumbuhan bagi pengelola gereja adalah pelayanan sosial.

Dari sejumlah responden yang diwawancara oleh penulis maka sebagaian responden yang mengatakan bahwa bentuk penerapan konsep pelayanan holistik bagi pengembangan pelayanan penggembalaan dalam gereja adalah pelayanan yang menyentuh

\footnotetext{
${ }^{14}$ Katrin Nussi, Wawancara Oleh Penulis, Jayapura, ll Juni 2013.

${ }^{15}$ Vence Yesianda, Wawancara Oleh Penulis, Jayapura, 06 Juni 2013.
} 
dalam bidang sosial. Enny Wahongan mengatakan, "Penggembangan pelayanan sosial adalah pelayanan yang sangat berhubungan dengan kebutuhan hari-hari jemaat sebagai masyarakat sosial dalam lingkungan di mana dia berada, maka gereja dapat menyediakan kebutuhan jemaat lewat sebuah wadah yaitu koperasi, karena akan berdampak pada pendapatan dan ekonomi jemaat akan meningkat."16

Pemahaman serupa menurut Adomina Sembari Kaiba, "Pelayanan sosial seringkali kurang mendapat perhatian bahkan terkesan diabaikan oleh gereja terhadap masyarakat yang mengalami keterbatasan, kekurangan dan ketidakadilan. Oleh karena itu, gereja perlu memberikan perhatian kepada mereka dengan jalan melengkapi sarana prasarana guna menjawab kebutuhan mereka seperti, bidang Pendidikan Anak Usia Dini (PAUD) dengan moto menjangkau yang tidak terjangkau." ${ }^{17}$ Dalam hal ini penulis juga melihat peluangpeluang yang dapat dikembangkan guna menjawab kebutuhan sosial jemaat seperti pembukaan tempat penitipan anak, tempat pencucian motor dan mobil, bahkan dengan lokasi gereja yang memungkinkan untuk membuka kebun sayuran dan tempat penginapan. Menurut Jhon Sikora, "Pelayanan yang paling cocok untuk mengembangkan pelayanan sosial pada dua tempat penanaman gereja baru yang dikembangkan oleh Gereja Kemah Injil Indonesia (GKII) Jemaat Yegar Sahaduta adalah di daerah Keroom dan Koya Barat perbatasan dengan Papua New Guinea. Gereja juga terpanggil untuk melengkapi dengan keterampilan dan pembiayaan dana sehingga dapat mengembangkan potensi sebagai syarat dalam peningkatan ekonomi jemaat. Jemaat tidak lagi tergantung pada alam yang memanjakan lagi, tetapi mampu menciptakan lapangan pekerjaan dan pendapatan yang memadai, semua ini dapat dikelola lewat koperasi gereja." ${ }^{18}$

Dari data responden dan hasil pengamatan penulis sebagai gembala yang telah dijabarkan penulis di atas, maka penulis dapat menarik kesimpulan bahwa pelayanan sosial sangatlah penting untuk diterapkan pada Gereja Kemah Injil Indonesia (GKII) Jemaat Yegar Sahaduta Jayapura, sebagai upaya peningkatan taraf hidup ekonomi jemaat yang berada di daerah Keroom, Koya Barat maupun di Dok 9 Jayapura. Dengan adanya pelayanan tersebut dapat memudahkan pengembangan potensi yang ada sebagai upaya untuk meningkatkan taraf hidup secara ekonomi, dan rohani jemaat yang berdampak bagi pertumbuhan penggembalaan dalam gereja. Jadi gereja tidak saja melayani jiwanya untuk diselamatkan, akan tetapi memikirkan pelayanan yang bersifat sosial. Isi pelayanan pastoral sama dengan isi

\footnotetext{
${ }^{16}$ Enny Wahongan, Wawancara Oleh Penulis, Jayapura, ll Juni 2013.

${ }^{17}$ Adomina Kaiba, Wawancara Oleh Penulis, Jayapura, 30 April 2013.

${ }^{18}$ John Sikora, Wawancara Oleh Penulis, Jayapura, 10 Juni 2013.
} 
Injil. Dan karena Injil mencakup seluruh hidup manusia, itu berarti pelayanan holistik adalah pelayanan yang menyangkut kehidupan manusia seutuhnya.

Berdasarkan hasil wawancara yang dilakukan terhadap beberapa responden dan dibuktikan dengan pengamatan penelitian oleh penulis, maka sebagian besar responden yang mengatakan bahwa pelayanan dalam bidang, mencari pekerjaan sangat menonjol dan penting untuk dilaksanakan sebagai sarana guna menjalankan misi Allah di tengah dunia ini.

Fransina Kaiba, ketua pemuda Gereja Kemah Injil Indonesia Jemaat Yegar Sahaduta Jayapura menjelaskan, "Peran dan fungsi pemuda sangat dibutuhkan guna menunjang pertumbuhan dan perkembangan gereja dalam hal ini pemuda mengambil peran dalam menjalankan visi dan misi gereja untuk membawa sejahtera bagi warga jemaat dengan menjalankan program-program strategis dalam Jemaat." ${ }^{, 19}$

\section{Mempersiapkan dan Membuka Lapangan Pekerjaan}

Pelayanan holistik merupakan pelayanan yang berkesinambungan dalam rangka memberi jalan keluar yang tepat sesuai dengan kearifan lokal yang ada di Jayapura Papua. Untuk itu gereja membutuhkan orang-orang yang berkomitmen tinggi untuk memajukan gereja Tuhan di Jayapura

Jhon Sikora mengatakan, "Sudah waktunya Gereja mengelola aset-aset yang ada secara professional artinya organisme yang ada dalam gereja itu harus dikembangkan secara baik agar nampak bahwa gereja betul-betul hadir dalam dunia untuk menjawab apa yang merupakan kebutuhan dari warga jemaat itu sendiri. Gereja sudah waktunya melihat peluang-peluang yang ada dalam masyarakat yaitu dengan mengembangkan suatu bidang usaha seperti Yayasan yang mengelola semua bidang usaha dalam gereja. Tentu dengan memperhatikan program strategis dari jemaat untuk dikembangkan secara profesional dengan mempersiapkan sumber daya manusia yang dapat menjawab kebutuhan untuk dipekerjakan sebagai tenaga terampil. ${ }^{20}$

\section{Pengembangan PAUD dan Tempat Penitipan Anak}

Pengembangan PAUD dan tempat penitipan anak adalah bagian dari panggilan gereja untuk menjawab kebutuhan orang-orang perkotaan. Exy Karubuy Kayoi mengatakan, "Program pendidikan anak usia dini merupakan tren positif dewasa ini karena begitu

\footnotetext{
${ }^{19}$ Fransina Kaiba, Wawancara Oleh Penulis, Jayapura, 30 April 2013.

${ }^{20}$ John Sikora, Wawancara Oleh Penulis, Jayapura, 10 Juni 2013.
} 
banyak orang tua maupun anak-anak mereka mendapat pendidikan yang lebih baik dan terjaga kenyamanan dan keamanan anak tersebut. Maka kami akan kembangkan pendidikan anak usia dini sebagai program primadona dalam pengembangan dan pertumbuhan gereja secara kualitas dan kuantitas. Tentu dengan adanya pendidikan anak usia dini dan tempat penitipan anak memerlukan tenaga kerja terampil yang disiapkan gereja untuk pekerjaan tersebu. ${ }^{21}$ Fera Gedy mengatakan, "Dalam mencapai program-program plus, maka sekolah dan pihak gereja harus bekerja sama untuk mencapai visi dari sekolah itu. Adapun visi pendidikan anak usia dini adalah "Menjangkau yang tidak terjangkau", visi ini memberikan pencerahan kepada orang tua dan keluarga bahwa pendidikan itu sangat penting dan jangan menghalangi anak untuk datang kepada Yesus lewat pendidikan anak usia dini. ${ }^{22}$

\section{Menjadi Penghubung Mendapati Lahan dan Pemukiman Baru}

Pengembangan Kota Jayapura semakin hari semakin padat dan mengalami kesulitan mendapatkan lahan kosong guna mengembangan gereja atau usaha yang dikelola oleh gereja. Dilihat dari kepadatan Kota Jayapura untuk beberapa tahun ke depan, maka gereja sudah harus memikirkan lahan baru dan penanaman gereja baru. Pembukaan pemukiman baru merupakan dampak dari kepadatan penduduk dalam suatu kota dan dampak dari kehidupan ekonomi yang mendesak, maka lewat gereja diadakan pendekatanpendekatan kepada masyarakat adat pemilik hak ulayat, maka disepakati guna pemberian tanah adat suku Bate yang berkedudukan di Kabupaten Kerom, dan jemaat sangat berantusias untuk memilikinya. Markus Kayoi mengatakan, "Dengan adanya pemukiman baru ini maka gereja pun terlibat dalam mencari dan memenuhi kebutuhan jemaat akan perumahan. Inilah yang disebut pelayanan secara holistik, tidak saja menjawab kebutuhan rohani dari jemaat, tetapi gereja selama masih berada di dunia harus bisa menjawab kebutuhan jasmani jemaat. Berdasarkan pengamatan penulis juga didapati bahwa rumah merupakan kebutuhan manusia yang masih berada dalam dunia dan tidak dapat ditunda karena rumah adalah bagian dari kehidupan kita sebagai orang percaya dan keturunan kita ke depan. ${ }^{23}$ Memahami akan kebutuhan rumah dan pengembangan gereja ke depan, maka sebagai gembala jemaat melihat ini sebagai kebutuhan dan peluang untuk mengembangkan dan pembukaan daerah pelayanan yang baru.

\footnotetext{
${ }^{21}$ Exie Karubui Kayoi, Wawancara Oleh Penulis, Jayapura, 19 Mei 2013.

${ }^{22}$ Vera Gedi, Wawancara Oleh Penulis, Jayapura, 19 Mei 2013.

${ }^{23}$ Markus Kayoi, Wawancara Oleh Penulis, Jayapura, 25 Juni 2013.
} 


\section{Hambatan Penerapan Pelayanan Holistik di GKII Jemaat Yegar Sahaduta Jayapura}

\section{Pemahaman Tentang Pelayanan Holistik dari Anggota Jemaat}

Berdasarkan hasil pengamatan penulis dan wawancara dari sejumlah responden di Gereja Kemah Injil Indonesia (GKII) Jemaat Yegar Sahaduta Jayapura, maka ada dari responden mengatakan bahwa pelayanan holistik belum terlalu banyak dipahami oleh sebagian jemaat, ini disebabkan karena kurangnya sosialisasi rutin dari pihak gereja dalam hal ini adalah gembala jemaat.

Menurut Naomi Karaeng Unggu, "Untuk dapat memahami pelayanan holistik atau pelayanan yang bersifat menyeluruh, maka perlu pelatihan-pelatihan yang mengarah pada mendoktrinasi jemaat agar mereka dapat melaksanakan pelayanan holistik itu secara berkesinambungan, artinya konsep pikir dari jemaat diperbaiki dan mulai dilaksanakan. Pengembangan pelayanan secara holistik tidak mudah. Gereja diperhadapkan pada masalah yang tidak gampang untuk mengatasi persoalan-persoalan sosial, baik dalam jemaat maupun dalam masyarakat." ${ }^{24}$

Dalam hal ini Emmy Mariani mengatakan bahwa, "Kurangnya pemahaman tentang pelayanan holistik pada Gereja Kemah Injil Indonesia Jemaat Yegar Sahaduta Jayapura membuat jemaat tidak mengerti dan memahami makna dari pelayanan holistik tersebut sehingga jemaat bersifat apatis atau masa bodoh terhadap pelayanan holistik. Berangkat dari kurangnya pemahaman dan tindakan nyata terhadap pelayanan holistik, maka gembala, majelis jemaat serta semua unsur dalam jemaat harus menyatukan program pelayanan dengan arah dan tujuan yang sama yaitu mengembangkan pelayanan holistik. ${ }^{25}$

Berdasarkan uraian dari hasil wawancara responden dan pengamatan oleh penulis di lapangan, maka dapat ditarik kesimpulan bahwa hambatan-hambatan yang dihadapi oleh Gereja Kemah Injil Indonesia Jemaat Yegar Sahaduta Jayapura dalam melaksanakan pelayanan holistik adalah kurangnya sosialisasi terhadap pelayanan tersebut itu sehingga jemaat menjadi bingung dalam melaksanakannya. Untuk itu, perlu melibatkan semua unsur, majelis dan Gembala Jemaat untuk bersinergi guna mencapai pengembangan gereja yang misioner, yaitu gereja yang mampu menjalankan programprogram strategis guna memenangkan banyak jiwa datang kepada Yesus Kristus.

\footnotetext{
${ }^{24}$ Naomi Karaeng Unggu, Wawancara Oleh Penulis, Jayapura, 10 Juni 2013.

${ }^{25}$ Emmy Mariani, Wawancara Oleh Penulis, Jayapura, 08 Juni 2013.
} 


\section{Pendanaan dalam Pengembangan Pelayanan Holistik}

Berdasarkan hasil wawancara yang diperoleh dari sejumlah respoden oleh penulis dan pengamatan sebagai gembala jemaat, serta melihat dari pemasukan kolekte untuk menunjang pelayanan holistik sangatlah minim. Sebagian responden memberikan jawaban bahwa faktor utama yang menghambat pelayanan holistik adalah masalah dana, karena hampir sebagian besar pengembangan pelayanan holistik memerlukan dana. Jhon Sikora mengatakan bahwa, mindset dari warga jemaat yang perlu diubah dulu baru dari situ mereka dapat dana yang cukup, maka semua program yang telah disusun dengan baik tidak terkendala. Oleh karena itu, gereja harus mengembangan pelayanan yang bisa mendatangkan pemasukan guna menjawab dan menerapkan pelayanan holistik guna mencapai pertumbuhan gereja secara baik. ${ }^{26}$

Uraian yang sama juga dikatakan oleh Vence Yesianda, bahwa Gereja Kemah Injil Indonesia Jemaat Yegar Sahaduta Jayapura masih mengalami kesulitan atau keterbatasan dana, mengingat jemaat masih dikatagorikan pada tingkat pendapat yang masih kurang atau rendah. Oleh sebab itu, masalah dana sering menjadi penghambat dalam pelayanan guna menjangkau jiwa-jiwa yang marginal di sekitar tempat pelayanan. ${ }^{27}$ Dari hasil data wawancara dari sejumlah respoden dan pengamatan penelitian oleh penulis yang juga sebagai gembala, maka dapat ditarik suatu kesimpulan bahwa faktor dana yang tidak banyak tersedia guna mengembangkan pelayanan holistik mengalami hambatan-hambatan bagi pengembangan pelayanan holistik guna mencapai visi dan misi gereja yaitu pengembangan dan penanaman gereja baru.

\section{Orang-Orang Terampil dalam Pelayanan Holistik}

Papua memerlukan orang-orang terampil dalam pengembangan gereja Tuhan ke depan, sumber daya manusia dalam gereja pun mengalami persoalan, karena masalah ketenagaan dan pengkaderan yang belum dapat menjawab kebutuhan pelayanan.

Berdasarkan hasil wawancara dari sejumlah responden bahkan peneliti sebagai gembala jemaat, maka sebagian responden mengatakan bahwa hambatan yang paling menonjol dalam pengembangan pelayanan secara holistik adalah kurangnya sumber daya manusia dalam gereja yang siap dipakai dalam pelayanan holistik.

\footnotetext{
${ }^{26}$ John Sikora, Wawancara Oleh Penulis, Jayapura, 10 Juni 2013.

${ }^{27}$ Vence Yesianda, Wawancara Oleh Penulis, Jayapura, 06 Juni 2013.
} 
Frans Nuboba sebagai seorang ahli hama pada tumbuhan mengatakan, "Bahwa ke depan gereja sudah harus memikirkan persoalan yang urgen ini, yaitu sumber daya manusia. Dari sinilah terlihat hambatan-hambatan karena lemahnya anggota jemaat yang siap diberikan tanggung jawab dalam melaksanakan pelayanan holistik, maka gereja perlu mengadakan pelatihan-pelatihan atau mengikutsertakan anggota jemaat mengikuti pelatihan-pelatihan mengenai keterampilan yang diadakan oleh pemerintah ataupun gereja. ${ }^{28}$

Hal senada diungkapkan oleh Nova Ruamba mengatakan, bahwa guna menjawab persoalan dalam pelayanan yang berhubungan dengan sumber daya manusia perlu melibatkan pemuda-pemudi gereja sebanyak mungkin agar di kemudian hari itu sebagai aset dalam pengembangan gereja. Kalau gereja mempersiapkan tenaga-tenaga yang terampil, maka akan berdampak bagi gereja karena pola pikir dan tingkat pemahaman tentang pelayanan holistik semakin baik dan dapat menjawab kebutuhan akan sumber daya manusia guna dilibatkan dalam pekerjaan Tuhan. ${ }^{29}$

Berdasarkan hasil wawancara oleh penulis dan pengamatan penulis sebagai gembala, maka dapat ditarik kesimpulan, bahwa sumber daya manusia dalam pelayanan Gereja Kemah Injil Indonesia Jemaat Yegar Sahaduta Jayapura sangat memengaruhi pemahaman yang benar tentang arah dan tujuan pelayanan holistik itu sendiri. Untuk itu, gereja perlu memikirkan langkah-langkah strategis untuk memenuhi kebutuhan ini. Oleh karena itu untuk meningkatkan sumber daya manusia, maka gereja mengembangkan dan mendirikan pendidikan secara formal kepada anak-anak dalam lingkungan gereja seperti PAUD dan TK, dan pendidikan pelatihan bagi orang dewasa sebagai strategi bagi pengembangan gereja Tuhan ke depan.

\section{Langkah-Langkah Penerapan Pelayanan Holistik di GKII Yegar Sahaduta Jayapura}

Segala sesuatu mempunyai jalan keluar yang kita sebut sebagai langkah-langkah strategis guna menjawab problema yang dihadapi oleh gereja Tuhan. Adapun langkah-langkah tersebut berdasarkan hasil wawancara dari sejumlah responden serta dikuatkan dengan pengamatan penulis sebagai gembala jemaat pada tempat penelitian, maka muncul buah pikiran yang berpotensi untuk memajukan pekerjaan Tuhan lewat pelayanan holistik antara lain:

\footnotetext{
${ }^{28}$ Frans Nuboba, Wawancara Oleh Penulis, Jayapura, 25 April 2013.

${ }^{29}$ Nova Ruamba, Wawancara Oleh Penulis, Jayapura, 30 April 2013.
} 


\section{Meningkatkan Sosialisasi Tentang Pelayanan Holistik}

Pemahaman pelayanan holistik dalam Gereja Kemah Injil Indonesia Jemaat Yegar Sahaduata mendapat perhatian yang serius dari warga jemaat karena pelayanan holistik ini sebenarnya sudah dilaksanakan, namun ada hal-hal yang perlu dipahami dan dimengerti dengan baik oleh warga jemaat untuk diperjelas lagi.

Patriot Kayoi menjelaskan bahwa pelayanan holistik dalam pengertian secara menyeluruh dalam bidang diakonia, meningkatkan ekonomi jemaat dan pengembangan sumber daya manusia perlu ditingkatkan lagi agar dikemudian hari gereja memiliki tenaga-tenaga terampil guna memajukan gereja dari berbagai macam sudut pandang, tentu dengan maksud menyejahterakan warga Gereja Kemah Injil Indonesia Jemaat Yegar Sahaduta Jayapura Papua. ${ }^{30}$ Sosialisasi adalah bagian dari strategi guna membawa jemaat Tuhan paham akan arah dalam pencapaian visi dan misi Gereja Kemah Injil Indonesia Jemaat Yegar Sahaduta. Jadi, pemahaman akan pelayanan holistik perlu dipahami secara benar dan tepat, maka pencapaian akan program pelayanan holistik dapat terwujud.

\section{Pengembangan Yayasan Yegar Sahaduta Secara Profesional}

Berdasarkan wawancara yang dilakukan terhadap sejumlah responden dan pengamatan penulis sebagai gembala jemaat tersebut, maka sebagian responden mengatakan bahwa peningkatan kualitas gereja dan semua unsur dalam gereja harus mempunyai satu badan dalam gereja, yaitu yayasan yang dikelola secara profesional. Jhon Sikora sebagai majelis senior mengatakan bahwa yayasan sudah ada tinggal bagaimana gereja mengadakan regulasi-regulasi dalam pengelolaan yayasan dimaksud. Yayasan sudah ada sekarang bagaimana pengelola yayasan ini dengan penuh tanggung jawab memonitoring semua kegiatan pelayanan secara holistik. ${ }^{3 .}$

Elisa Unggu salah seorang pendiri Gereja Kemah Injil Indonesia Jemaat Yegar Sahaduta mengatakan bahwa yayasan kalau dikelola dengan professional, maka akan berdampak bagi gereja dan umat Tuhan. Tentu gereja dalam hal ini yayasan harus memperhatikan perubahan-perubahan aturan agar masalah legalitas yayasan aman untuk dipergunakan bagi perkembangan pelayanan gereja secara holistik dan dapat menikmati dampak dari pelayanan yayasan Yegar Sahaduta. ${ }^{32}$

\footnotetext{
${ }^{30}$ Patriot Kayoi, Wawancara Oleh Penulis, Jayapura, 28 April 2013.

${ }_{32}^{31}$ John Sikora, Wawancara Oleh Penulis, Jayapura, 10 Juni 2013.

${ }^{32}$ Ellisa Ungguh, Wawancara Oleh Penulis, Jayapura, 16 Juni 2013.
} 


\section{Membentuk Wadah Koperasi Gereja}

Berdasarkan hasil pengamatan dan observasi penulis sebagai gembala jemaat dan wawancara sejumlah responden mengatakan bahwa pengembangan koperasi gereja itu sangat baik untuk peningkatan pendapatan gereja dan membantu warga sekitar gereja untuk menjawab kebutuhan pokoknya. Naomi Karaeng Unggu mengatakan, bahwa keunggulan koperasi gereja adalah turut melaksanakan program pemerintah Provinsi Papua dalam hal menyejahterakan masyarakat asli Papua, melalui koperasi gereja dapat memberikan kemudahan-kemudahan bagi umat Tuhan dalam mendapatkan sembilan bahan pokok dengan harga yang dapat dijangkau, bahkan melalui koperasi gereja kebutuhan pendidikan PAUD dan TK berupa pakaian seragam, alat tulis, makanan ringan dapat dijangkau. ${ }^{33}$

Sejalan dengan penjelasan diatas, Enny Yesianda mengatakan bahwa, "Melalui koperasi gereja dapat membuka lapangan pekerjaan baru bagi warga gereja secara khusus anak-anak muda yang belum mendapat pekerjaan, itu berarti gereja dapat memberikan kontribusi dalam hal mempersiapkan pekerjaan. Di sisi lain, pendapatan masyarakat dan gereja semakin membaik dengan adanya koperasi, bahkan kemampuan dari jemaat Tuhan dalam mempersiapkan beraneka macam kue dapat dijual melalui koperasi. ${ }^{34}$ Pelayanan koperasi sangat penting diterapkan dalam gereja sebagai sarana pengembangan pelayanan penggembalaan secara holistik. Sebagai gembala jemaat, penulis melihat bahwa pengembangan pelayanan koperasi juga sebagai sarana dalam pemberitaan Injil Kristus karena diperhadapkan dengan jemaat bahkan warga masyarakat di sekitar gereja.

Jadi, hasil dari sejumlah wawancara responden yang telah dijabarkan oleh penulis, maka dapat ditarik beberapa hal yang bisa dipergunakan dalam pengembangan pelayanan di Gereja Kemah Injil Indonesia Jemaat Yegar Sahaduta Jayapura Papua sangatlah penting dan dibutuhkan dalam peningkatan ekonomi dan pendapatan jemaat, bahkan yang tidak kalah penting, yaitu membuka atau menciptakan lapangan pekerjaan baru bagi warga jemaat dan masyarakat di sekitar gereja. Dari sini juga gereja dapat mengembangkan, mempraktekkan sistem penginjilan praktis bagi jiwa-jiwa yang belum percaya Yesus sebagai Tuhan dan Juruselamat pribadi.

\footnotetext{
${ }^{33}$ Naomi Karaeng Unggu, Wawancara Oleh Penulis, Jayapura, 11 Juni 2013.

${ }^{34}$ Enny Wahongan, Wawancara Oleh Penulis, Jayapura, ll Juni 2013.
} 


\section{Penggembangan Pendidikan PAUD dan TK Secara Profesional}

Pendidikan anak usia dini adalah bagian dari mencerdaskan kehidupan bangsa dan negara, bahkan anak yang dididik di usia dini akan menghasilkan kualitas yang baik sehingga gereja menemukan sumber daya manusia yang berkualitas di kemudian hari.

Berdasarkan hasil wawancara terhadap sejumlah responden dan pengamatan penulis sebagai gembala jemaat, maka sebagian responden mengatakan bahwa pada hakekatnya pelayanan pendidikan anak usia dini dan taman kanak-kanak merupakan pelayanan pembentukan karakter dan kepribadian anak dari usia dini. Ekxi Karubui Kayoi mengatakan, bahwa pendidikan anak usia dini dan taman kanak-kanak merupakan hal yang penting untuk dilakukan oleh para guru dalam konsep pelayanan seutuhnya, maka dewan guru dan pengelola sekolah dapat mengetahui pertumbuhan anak didik satu persatu. ${ }^{36}$ Vera Gedy menjelaskan bahwa penerapan konsep pelayanan kepada anak sangat berbeda maka memerlukan keahlian khusus. Untuk dapat menjawab kekhususan itu, maka para pendidik perlu membekali diri dengan pengetahuan. Untuk mengembangkan pendidikan PAUD dan TK secara profesional, maka guru perlu melanjutkan pendidikan pada jenjang yang lebih tinggi, misalnya SI PAUD pada Universitas Cendrawasih Jayapura. ${ }^{35}$

Menurut Ferderika Talane, bahwa pelayanan pendidikan anak usia dini dan TK harus dimulai dari hati yang terpanggil dan mencintai anak-anak didik agar secara langsung berita tentang Yesus Kristus sebagai Tuhan dan Juruselamat diterima dan dimengerti oleh anak-anak. Pelayanan anak usia dini dan TK adalah bagian dari pelayanan seutuhnya atau holistik karena menyentuh semua unsur kehidupan dari anak didik, yaitu pembentukan motorik dan pengenalan akan Tuhan Yesus sebagai Tuhan dan Juruselamat kehidupan anak. ${ }^{36}$

\section{Kesimpulan}

Pertama, dari fakta penelitian sebagian warga Gereja Kemah Injil Indonesia Jemaat Yegar Sahaduta sudah mempraktikkan pelayanan secara holistik, dengan mengembangkan pelayanan diakonia, tetapi makna pelayanan holistik yang sebenarnya belum dipahami secara baik, benar dan tepat yaitu menyangkut tubuh, jiwa, dan roh.

Kedua, Gereja Kemah Injil Indonesia Jemaat Yegar Sahaduta, mengembangkan bentuk-bentuk pelayanan yang dapat menjawab

\footnotetext{
${ }^{35}$ Vera Gedi, Wawancara Oleh Penulis, Jayapura, 18 Mei 2013.

${ }^{36}$ Frederika Talane, Wawancara Oleh Penulis, Jayapura, 19 Mei 2013.
} 
pergumulan jemaat secara utuh atau menyeluruh yaitu pelayanan holistik. Adapun strategi yang dikembangkan oleh gereja adalah memfasilitasi atau menciptakan lapangan pekerjaan baru dengan sasaran jemaat.

Ketiga, Gereja dalam mempersiapkan lapangan pekerjaan yang baru tentu dengan memperhatikan kebutuhan-kebutuhan dari umat Tuhan. Dengan pengelolaan pendidikan anak usia dini, taman kanakkanak dan tempat penitipan anak dengan visi menjangkau yang tidak terjangkau. Ini merupakan satu strategi untuk memberdayakan anggota jemaat secara khusus para janda-janda serta peduli juga kepada para pemuda yang ada dalam persekutuan bergereja, agar gereja menemukan sumber daya manusia dan strategi penggembalaan pun bisa tercapai.

Keempat, Gereja Kemah Injil Indonesia Jemaat Yegar Sahaduta, dalam melaksanakan pelayanan secara holistik memiliki langkahlangkah dengan meningkatkan kegiatan-kegiatan yang mengarah kepada pelayanan secara holistik, maka secara tidak langsung gembala bersama badan pengurus jemaat mensosialisasikan kegiatan pelayanan secara holistik. Langkah strategis yang lain, yaitu mengembangkan pendidikan anak usia dini, taman kanak-kanak dan tempat penitipan anak secara profesional, guru memiliki pengetahuan yang baik tentang pertumbuhan anak. Dari pendidikan PAUD, TK dan Tempat Penitipan Anak, maka pelayanan gereja kepada anak maupun orang tua dalam memperkenalkan Yesus Kristus semakin terbuka, gereja juga membuka lapangan pekerjaan bagi anggota jemaat serta memperbaiki ekonomi keluarga dalam jemaat. Dari sinilah pintu masuk untuk melaksanakan pelayanan pastoral penggembalaan dengan konseling pribadi, kelompok sel grup, ibadah sektor, seminar tentang pengenalan akan karunia, serta melakukan tindakan-tindakan nyata dalam mewujudkan panggilan gereja yang melayani secara marturia, koinonia, dan diakonia.

Kelima, Gereja Kemah Injil Indonesia Jemaat Yegar Sahaduta, mencermati bahwa pelayanan holistik tatkala dikembangkan secara profesional, maka akan memberikan dampak bagi pertumbuhan jemaat, baik secara kualitas maupun kuantitas, jemaat diberdayakan untuk mandiri dalam melaksanakan fungsinya sebagai anggota jemaat dan warga masyarakat, bahkan masyarakat di sekitar gereja merasakan dampak dari pelayanan secara holistik, baik secara jasmani maupun secara rohani dan pada akhirnya dia mengambil keputusan untuk menjadi anggota jemaat tetap. 


\section{KEPUSTAKAAN}

\section{Buku-Buku}

Barna, George. Memasarkan Gereja. Bandung: Kalam Hidup, 1988.

Parjiyanto, Al. et. al. Jamrut: SMP Agama Kristen Kelas IX. Solo: CV. Yoga Wahyu Pratama, n.d.

Riggs, Ralph M, Gembala Sidang Yang Berhasil. Malang: Yayasan Penerbit Gandum Mas, 1996.

\section{Internet}

Sabda, diakses 27 Oktober 201l, http://alkitab.sabda.org/resource. php?topic=493\&res=jpz.

\section{Wawancara}

Daisiu, Petrus. Wawancara Oleh Penulis, Jayapura, 02 Juni 2013.

Kaiba, Adomina. Wawancara Oleh Penulis, Jayapura, 30 April 2013. Karubuay, Exi. Wawancara Oleh Penulis, Jayapura, 19 Mei 2013.

Kayoi, Exie Karubui. Wawancara Oleh Penulis, Jayapura, 19 Mei 2013. Kayoi, Markus. Wawancara Oleh Penulis, Jayapura, 25 Juni 2013. Kayoi, Patriot. Wawancara Oleh Penulis, 19 Juni 2013. Lawerissa, Silvana. Wawancara Oleh Penulis, Jayapura, 12 Mei 2013. Mangku, Antomina. Wawancara Oleh Penulis, ll Juni 2013.

Mariani, Emmy. Wawancara Oleh Penulis, Jayapura, 08 Juni 2013. Nuboba, Frans. Wawancara Oleh Penulis, Jayapura, 25 April 2013. Nuboba, Markus. Wawancara Oleh Penulis, Jayapura, 05 Juni 2012 Nussi, Katrin. Wawancara Oleh Penulis, 11 Juni 2013.

Ruamba, Nova. Wawancara Oleh Penulis, Jayapura, 07 April 2013. Ruamba, Theo. Wawancara Oleh Penulis, Jayapura, 15 Januari 2013. Sikora, John. Wawancara Oleh Penulis, Jayapura, 10 Juni 2013.

Unggu, Naomi Karaeng. Wawancara Oleh Penulis, Jayapura, 10 Juni 2013.

Wahongan, Enny. Wawancara Oleh Penulis, Jayapura, 11 Juni 2013.

Watimena, Eko. Wawancara Oleh Penulis, 10 Juni 2013.

Yesianda, Vence. Wawancara Oleh Penulis, Jayapura, 06 Juni 2013. 